Session 3453

\title{
Engineers Need Mentors Too!
}

\author{
Sayward H. Touton ${ }^{1}$, Cory P. McDonald ${ }^{1}$ \\ Gretchen L. Hein', Amy E. Monte ${ }^{2}$ \\ Department of Civil and Environmental Engineering ${ }^{1}$ \\ Department of Engineering Fundamentals ${ }^{2}$ \\ Michigan Technological University \\ Houghton, MI
}

\begin{abstract}
The Graduate, Undergraduate Initiative for Development and Enhancement (GUIDE) program at Michigan Technological University (MTU) is a unique scholarship program that couples underrepresented students with mentors for their first year in engineering. The goal of GUIDE is to stimulate academic success through the example set by each mentor. Each first year student, or mentee, is mentored by a second year undergraduate student and a graduate student. By structuring the groups in this manner, the mentee receives advice from two different perspectives and experiences. Having just completed their first year of college, the undergraduate mentor can better relate to, and therefore offer advice to typical first year concerns, such as how to approach a professor and where to go to get tutored in a specific subject. The graduate students are participating in the Peace Corps Master's International program in Civil and Environmental Engineering. These students typically have diverse interests and are service motivated. The graduate student mentor is also the team leader and guides both students based on his/her own college experience. Both mentors encourage good study habits, involvement in a professional engineering society, and career planning. Each group is required to meet at least twice a week to ensure that everyone is participating and to discuss issues of concern. Usually, the meetings are not all business. They are generally time to socialize and have fun together, because social interaction is important in developing relationships and gaining trust within the group. Some team activities have been: volunteering at the humane society, hiking to a local waterfall, and cooking dinner together. This paper will discuss the benefits of being a GUIDE scholar as well as the motivation necessary to ensure a successful first year experience in engineering.
\end{abstract}

\section{Introduction}

Always keep a mentor in your life. This advice should be heeded not only by young people, but by everyone, in every stage of life. Just think, if everyone modeled their life after someone they admired or who challenged them to be a better person, then each person would be a mentor to someone and a mentee, so to speak, to another. This lifelong process is a dynamic commitment 
not only to oneself, but also to one another. William James, an American philosopher of the 1800 s, understood the importance of mentorship as a way of life. He said "Act as though what you do makes a difference. It does."1

Although, it is advised to always keep a mentor in every stage of life, there are critical stages in life when having a mentor makes all the difference in successfully completing those stages. For example, the first year of college is an exciting, anxious and intimidating stage in life when the guidance of a mentor is especially valuable. An older student who has "been there, done that" can relate to a first year student in a way that professors, parents, and even a best friend cannot. The college experience is the link between the first year student and the mentor. The mentor can reflect on his/her own college experience while the mentee looks forward to making major life decisions. The mentor is willing to share the wisdom he/she gained from the experience and the mentee must be equally willing to learn from it. In short, mentoring is meant to assist the new students as they overcome the difficulties of transition in the first year. ${ }^{2}$ The GUIDE Scholarship program's main goal is to help engineering students in underrepresented groups succeed academically at the beginning of their college career by providing financial aid and personal mentoring. ${ }^{3}$

\section{The GUIDE Hierarchy}

The GUIDE Scholarship program at Michigan Technological University is a unique mentoring program that matches a graduate student, an undergraduate student and first year student to form a mentor/mentee team. By assigning teams in a three tiered hierarchy, each team member has a specific role in relation to the other two members.

The graduate student of the group is enrolled in a unique Master's of Science program at Michigan Tech called Master's International (M.I.). In this program graduate students will earn their M.S. in Civil or Environmental Engineering through volunteer service in the U.S. Peace Corps. Students in the M.I. program take courses for two semesters at Michigan Tech then serve for approximately two years as a water sanitation engineer in a developing country as a Peace Corps volunteer. This service is considered the equivalent of seven research credits. Upon completion in the Peace Corps, M.I. students must defend a project report, rather than a traditional thesis, detailing their accomplishments as a volunteer. These students, from across the country, were selected to be mentors in the GUIDE program because they typically have diverse interests and are service motivated. As the most academically experienced, the graduate students are the leaders of each group and responsible for mentoring both undergraduate students.

Having just completed their first year in the GUIDE scholarship program, the second year undergraduate students may have sophomore or junior status. They have exhibited a desire to continue an education in engineering and demonstrate financial need. The second year student is in a unique position in which he/she is both a mentee, under the graduate student, as well as a mentor to the first year student. He/she can share his/her own more recent first year experiences at Michigan Tech. 
Lastly and most importantly, the first year student has chosen to pursue a degree in an engineering discipline, is in an underrepresented group (i.e. female, minority), and exhibits financial need for the scholarship. Throughout the year, this student, or mentee, is able to receive advice from both the graduate and second year undergraduate students while fulfilling other requirements for the program.

\section{Requirements for GUIDE Scholars}

Graduate and undergraduate scholars in the GUIDE program must fulfill certain requirements each semester. At the beginning of the fall semester, the graduate and undergraduate mentors must attend an all-day training seminar for the GUIDE program. The purpose of this seminar is to familiarize the mentors with the learning centers and counseling services on campus; issues and factors affecting minority and women students in engineering and; issues affecting first and second year students' success/non-success. ${ }^{3}$ This training is to ensure that the mentors will be well equipped to meet the challenges that the first year students will soon face. At this seminar, the graduate and undergraduate mentors are assigned to their teams for the year and are able to get acquainted before meeting the first year student.

\section{Figure 1: Graduate and Undergraduate Mentors at the Training Seminar}

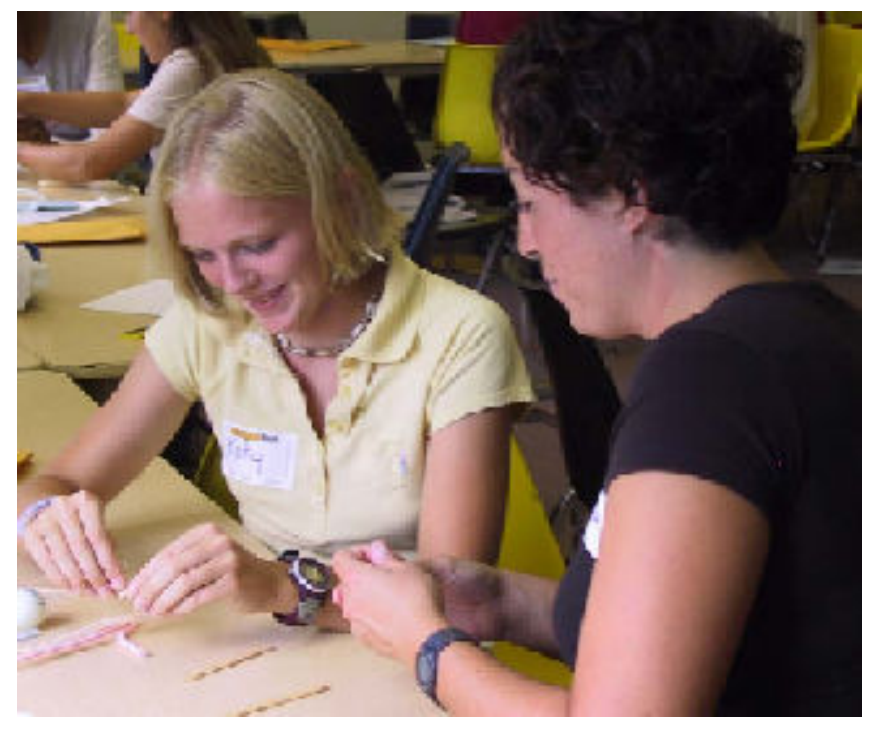

At the first GUIDE meeting of the fall semester, mentors and mentees are assigned to their teams for the year. In addition to the weekly GUIDE meeting, the mentoring teams meet twice a week outside of the class in a social setting. Initially, these meetings allow the students to get acquainted with one another. Once they are acquainted, the teams begin to plan activities and socialize more comfortably. (Social activities are discussed later in the paper.) Aside from participating in GUIDE activities, first year students are obligated to get involved in other organizations on campus. During the fall semester, these students must attend meetings in three different professional engineering societies and become an active member in one of them. ${ }^{3}$ Understanding the importance of incorporating academic and social life at the college level ${ }^{2}$, the GUIDE program encourages students to obtain a leadership position within that organization. 
The required weekly GUIDE meetings are set up as seminars given by local engineers, faculty, and graduate mentors throughout the year. These seminars offer students insight about various career options with an engineering degree. For example, one Civil Engineer discussed his career as a mathematics teacher in a local middle school. Another, a mechanical engineer reviewed the pros and cons of working in industry. Other career options that were discussed are outlined in Table 1 below. In addition to the seminars, career development workshops provide students with skills they will need in order to obtain an internship or co-op. The résumé writing workshop is particularly helpful to students who have never written a résumé. Table 1 also lists the various workshops that are planned for the students each year.

Table 1: Seminar and Workshop Series ${ }^{3}$ (2003-2004)

\begin{tabular}{|l|l|}
\hline Topic & Speaker(s)/Department \\
\hline Seminars & \\
\hline Program Intro - Pizza Party & Amy Monte \& Gretchen Hein \\
\hline Master's International Introduction & Graduate Mentors \\
\hline What to Expect as a First Year Student & Undergraduate Mentors \\
\hline The Pros and Cons of Working in Industry & $\begin{array}{l}\text { Mary Fran Desrochers, Mechanical } \\
\text { Engineering Technology }\end{array}$ \\
\hline Undergraduate Organizations & Student Representatives \\
\hline Career Opportunities & Campus-wide Career Fair \\
\hline Diversity (or Lack of) in Engineering & Debra Wright, Biomedical Eng \\
\hline Teaching as a Career Path & Matt Zimmer, Math Teacher \\
\hline Graduate School & Michele Miller, Mechanical Eng \\
\hline Social Activism in Engineering & Alex Mayer, Environmental Eng \\
\hline Undergraduate Research & Student Panel \\
\hline Local Politics \& Engineering & Brett Hamlin, General Eng \\
\hline Engineering Career Options & Sheryl Sorby, Associate Dean of Eng \\
\hline Wrap-Up Cookie Decorating & Amy Monte \& Gretchen Hein \\
\hline Workshops & \\
\hline Resume' Writing & James Turnquist, Career Center \\
\hline Resume' Critique & Career Center Staff \\
\hline Cover \& Thank-you Letters & James Turnquist, Career Center \\
\hline Career Choices \& FOCUS & James Turnquist, Career Center \\
\hline Mock Interviews & James Turnquist, Career Center \\
\hline Study Nationally, Abroad, Minors, Certifications & Amy Monte \\
\hline Co-op/Internship & Student Panel \\
\hline Enterprise Program & Student Panel \\
\hline &
\end{tabular}

In February, 2004 the graduate students organized a Mock Career Fair for the undergraduates (Figure 2). Each graduate student posed as a representative from an engineering firm or other company seeking to employ engineering students. This gave the undergraduates the opportunity to practice skills such as hand-shaking, maintaining eye contact and presenting their résumé to a potential employer. This also prepared the students for the actual Career Fair that was held at MTU the following week. 
Figure 2: GUIDE Students at Mock Career Fair

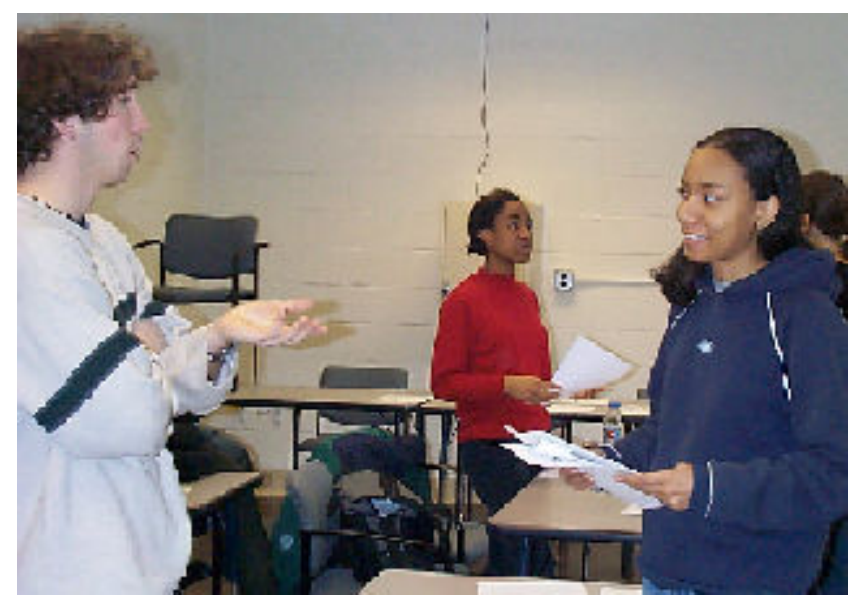

\section{GUIDE Demographics}

As previously stated, the GUIDE program is geared toward supporting students in underrepresented groups in their first year in engineering. Table 2 below shows the demographics of GUIDE scholars during the 2002-2003 and 2003-2004 academic years. There were six teams, each team consisted of two undergraduate students and one graduate student with the exception of one team that had two undergraduate, as well as, two graduate students. As shown below, the GUIDE program was able to assist 12 engineering students in its first year of establishment. Of the first year students, $43 \%$ were women and 57\% were minorities. Although there were less second year students than first year students, $60 \%$ were women and $20 \%$ were minorities in the undergraduate mentor position. ${ }^{3}$ As indicated in Table 2, participation in the GUIDE program increased in its second year.

Table 2: GUIDE Scholar Demographic Data (2002-2003 \& 2003-2004)

\begin{tabular}{|c|c|c|c|c|c|c|}
\hline \multirow{3}{*}{ Scholars } & \multirow{2}{*}{\multicolumn{2}{|c|}{ Total }} & \multicolumn{4}{|c|}{ Underrepresented Groups } \\
\hline & & & \multicolumn{2}{|c|}{$2002-2003$} & \multicolumn{2}{|c|}{ 2003-2004 } \\
\hline & $\begin{array}{l}2002- \\
2003 \\
\end{array}$ & $\begin{array}{l}2003- \\
2004 \\
\end{array}$ & $\begin{array}{c}\% \\
\text { Women } \\
\end{array}$ & $\begin{array}{c}\% \\
\text { Minority } \\
\end{array}$ & $\begin{array}{c}\% \\
\text { Women } \\
\end{array}$ & $\begin{array}{c}\% \\
\text { Minority } \\
\end{array}$ \\
\hline First Year & 7 & 8 & $43 \%$ & $57 \%$ & $88 \%$ & $13 \%$ \\
\hline Undergrad Mentor - Fall & 5 & 9 & $60 \%$ & $20 \%$ & $78 \%$ & $44 \%$ \\
\hline Undergrad Mentor - Spring & 5 & 8 & $60 \%$ & $20 \%$ & $75 \%$ & $50 \%$ \\
\hline Grad Mentor - Fall & 6 & 9 & $17 \%$ & $0 \%$ & $56 \%$ & $11 \%$ \\
\hline Grad Mentor - Spring & 7 & 9 & $29 \%$ & $0 \%$ & $56 \%$ & $11 \%$ \\
\hline Number of Teams & 6 & 8 & & & & \\
\hline
\end{tabular}


Tables 3 and 4 illustrate the summaries of majors of GUIDE students in the first two years of the program. These tables show that there was a wide variety of majors, except in the graduate mentor section in 2002-2003. The majority of these students received their B.S. degree in Civil or Environmental Engineering with the exception of one in Chemical Engineering. However, that is not the case for the 2003-2004 academic year. In the current year, there is more diversity of graduate mentors degrees which made it possible to match more mentors and mentees within a specific major. This academic year there are Civil Engineering, Mechanical Engineering, Materials Engineering, Chemical Engineering, Electrical Engineering and Environmental Engineering graduate students. Three teams contain students with similar academic interests. Those teams comprise of: two teams of mechanical engineering students and one team of chemical engineering students. These students have commented that they like that facet of their group. ${ }^{3}$

The other teams found their own common interests too. For instance, one group comprises of a first year electrical engineering student, a mechanical engineering undergraduate mentor, and a civil engineering graduate mentor, found that they could develop their relationships by supporting one another's extracurricular activities. When the first year student plays the viola in the Michigan Tech orchestra, the mentors are able to show support by attending the concerts.

Table 3: Summary of Majors: 2002-2003 Academic Year

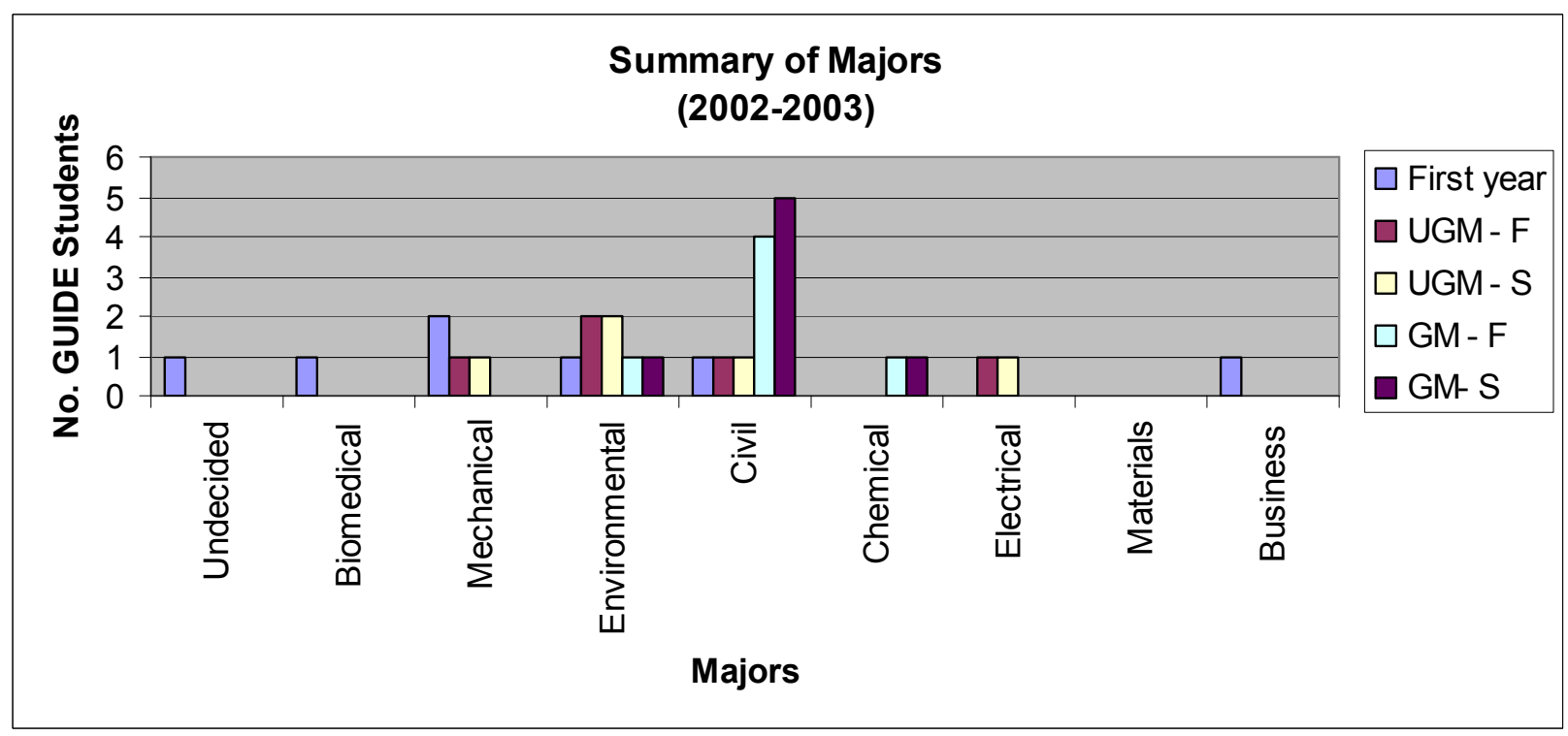


Table 4: Summary of Majors: 2003-2004 Academic Year

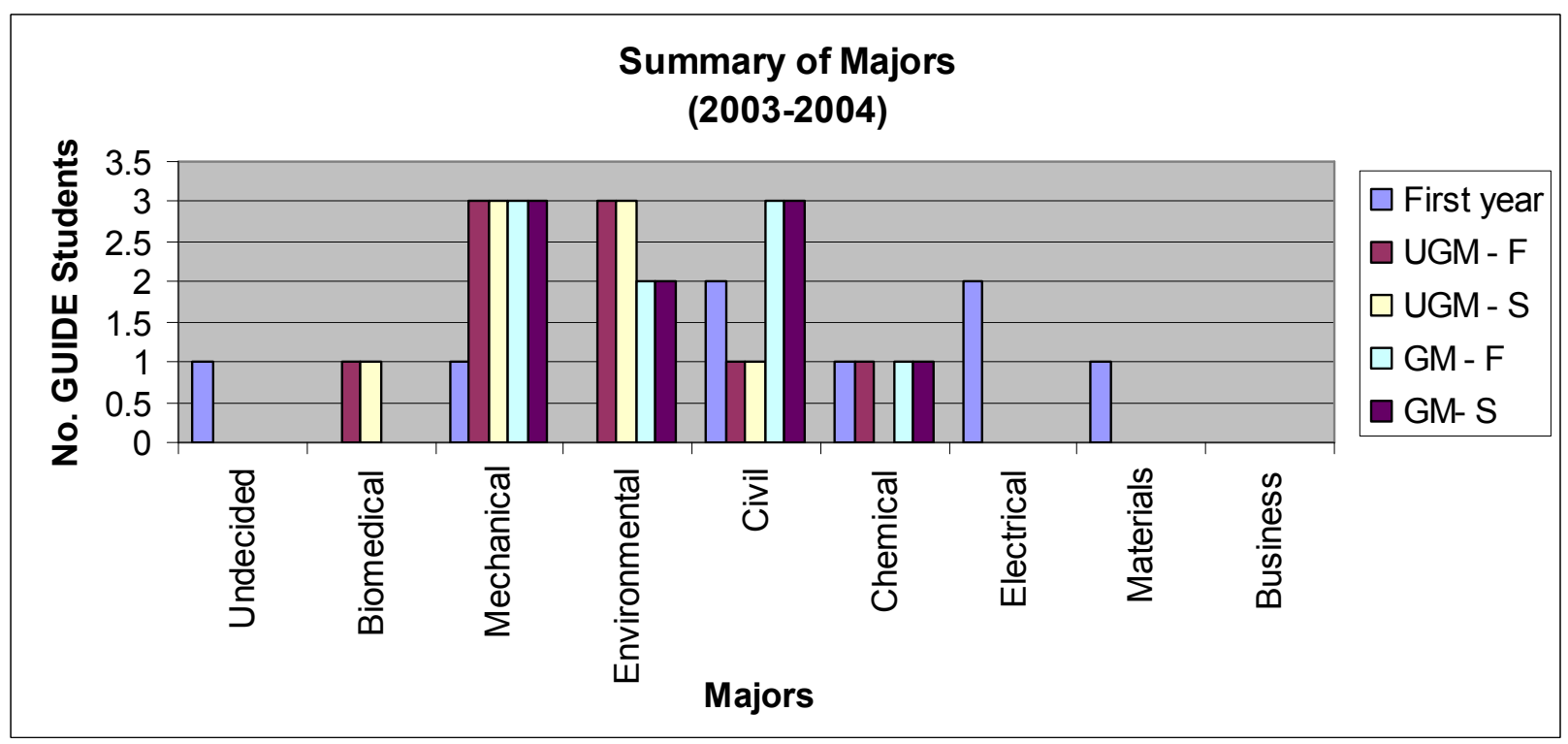

Legend: $\mathrm{UGM}-\mathrm{F}=$ Undergraduate Mentor during the fall semester

UGM $-\mathrm{S}=$ Undergraduate Mentor during the spring semester

$\mathrm{GM}-\mathrm{F}=$ Graduate Mentor during the fall semester

$\mathrm{GM}-\mathrm{S}=$ Graduate Mentor during the spring semester

\section{Social Activities}

The graduate mentor and team leader is responsible for arranging team meetings outside of the regularly scheduled GUIDE seminars. Studies regarding social interaction in the collegiate setting tend to support the notion that the development of personal relationships, namely with faculty and peers, "enables students to better cope with the demands of the college environment". ${ }^{2}$ With this in mind, these team meetings are meant to be informal and an opportunity to get acquainted on a more social rather than academic level. By socializing, the team members become more comfortable with one another and gain trust in sharing concerns with one another. Some team activities include cooking dinner together, snowshoeing, and walking dogs at a local animal shelter (see Figures $2 \& 3$ ). 


\section{Figure 3: GUIDE Students Snowshoeing}

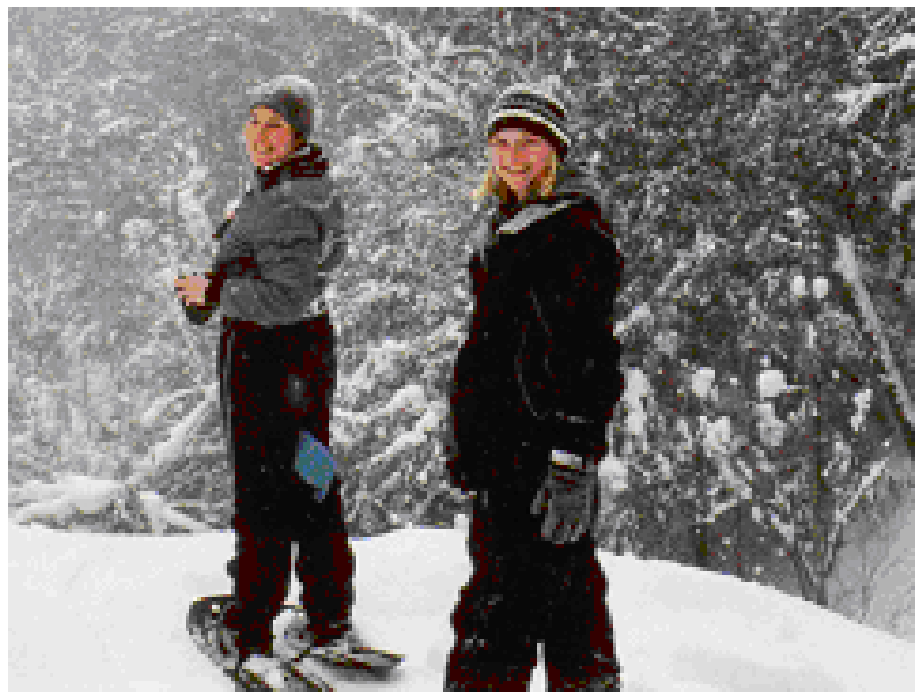

Figure 4: GUIDE Students Walking Dogs

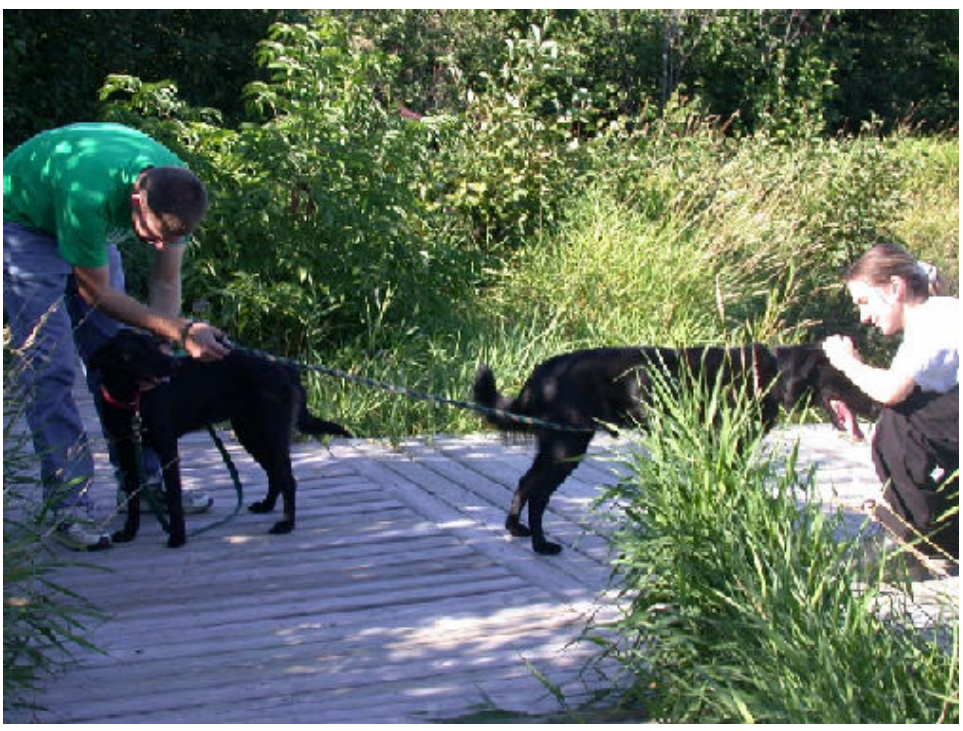

Usually, it is convenient for the teams to meet on campus for lunch and to catch up on things that happened during the week. Without the distractions of a planned activity, sitting down to a meal is an opportune time for the team to discuss any serious issues of concern. The mentor then takes the initiative to ask specific questions regarding courses, grades, etc. Although, these meetings are generally for socializing, academics are the focus of the GUIDE program and are the utmost concern for each mentor. After reviewing the grades from the fall 2003 semester, it is evident that two undergraduate students $(\mathrm{GPA}<3.0)$ could have benefited from more academic counseling. ${ }^{5}$ Furthermore, students with GPA's between 3.0 and 3.15, may have needed advising from their mentors but never sought it. For further information on the academic performance of the undergraduate students, see references [5] and [6]. 
There were two instances from last year, in which the mentor gave the mentee academic counseling and tutoring that had two different results. Even though much emphasis is placed on the mentor's academic counseling, there is still a link between student effort and learning. ${ }^{2}$ In fact, one student who received academic counseling from a dedicated mentor ultimately changed majors to the school of business. However, another mentor held study sessions with the mentee to bring up his/her grades. These examples are evidence that academic counseling is effective. Because of this, the current graduate mentors are taking an active role in helping the undergraduate students in the spring 2004 semester. They have implemented a weekly study session in a classroom on campus where several mentors are available to tutor in various subjects.

Other program improvements resulted from an interview conducted by Amy Monte. ${ }^{5}$ Five out of the nine teams interviewed acknowledged that they would like to get to know the other students in the entire group. They proposed that more out-of-class activities should be organized for everyone in the program. As a result, the logistics and leadership of these activities, along with the weekly study sessions, are currently being directed by the graduate mentors. ${ }^{5}$ One such activity for the GUIDE students was to attend an MTU hockey game, organized by one of the graduate mentors. This event proved successful, with approximately 18 students and the faculty advisors attending. By having a large group function, it gave everyone an opportunity to have a fun, relaxing time in a setting outside the classroom. Both mentors and mentees alike were able to get acquainted with members of the program that are not on their team. Other activities included sledding, snowshoeing, and skiing.

\section{GUIDE Survey Results}

In December 2003, an informal survey was conducted regarding the benefits of the GUIDE program (Appendix A). The questions were intentionally opened ended in order to focus on the students' impressions of the program overall. First, the students were asked to list the activities that their team participated in throughout the semester. Most of these activities were socially, not academically, related. When asked if the group meetings became comfortable or did it always feel forced, seven out of nine groups responded positively. However, only half of the participants agreed that they were comfortable sharing serious problems with their mentor. ${ }^{4}$

Aside from the financial aid provided by the program, many of the undergraduates shared the opinion that it was good to interact with their mentor. Primarily, the undergraduate students found their graduate mentor to be a good source of information about graduate school and the Peace Corps. With a few exceptions, the undergraduates expressed that having a mentor made it easier to come to college and helped them focus on the future rather than just "fitting in" a new place. ${ }^{4}$ Many of the undergraduate mentors also expressed that they sharpened their listening skills as they mentored the first year students. One student commented "I am more focused on the first year student as opposed to having all the attention on me."4

In addition to the social interaction of the program, the survey also evaluated the first year student's view of the weekly seminars and workshops. Six out of nine of these students said that the seminars were informative and they shared what they learned with their friends. One enthusiastic student even said that the seminars "make me believe in what I am doing; I come 
away from them excited". Only one person stated he/she did not find the seminars to be applicable, but offered no suggestions how to make improvements.

Results from the graduate mentors' perspective were almost evenly split. When asked if they understood the objectives of the GUIDE program and their role as a mentor, there were four positive responses. One said that the objectives were "explained pretty well in orientation; I believe in the program, so it was easy to buy into it." "However, five out nine had a negative response. These mentor's answers were basically alike; they felt that their mentees were not having a hard time academically or socially and that they really did not help them much. However, this opinion contradicts the previous statement regarding the undergraduates need for academic counseling. As it was found, several students could have had higher grades due to tutoring. Not only that, the mentors' perception was drastically different from the mentees' response to the survey. The mentees mention frequently their appreciation for the interaction with their graduate mentors. The overwhelming response from the mentees seems to be that they did indeed benefit socially from the interaction with the graduate mentors. ${ }^{4}$

In order to relay the results of the survey, a synopsis of both the positive and negative responses were discussed at the first large group meeting. The mentors need to understand their importance in the GUIDE program and know that they are truly appreciated. Moreover, the mentors also need to ask direct questions in order to be aware of the academic status of their mentees. In addition, the mentees have an advantage over many of their peers who do not have a mentor to guide them academically or socially. By utilizing this resource, they will have an even greater chance of success.

\section{Conclusion}

Students participating in this program indicated in the GUIDE Survey that having a mentor made adjusting to college life an easy transition. All the students currently in the program are pursuing an engineering degree. Most undergraduates selected a major at the beginning of the academic year. Some, on the other hand, are learning about each engineering discipline at the weekly seminars which will help them choose an engineering major. Of all the undergraduate students in GUIDE, only one has changed to a non engineering major, and no longer participates in the program.

Although there is always room for improvement, the GUIDE program strives each semester to provide its scholars with a successful start in their college career. With the many demands all college students face, including financial, academic and social, GUIDE is able to meet those needs through its uniquely structured program. In the four semesters that the program has been at Michigan Tech, over thirty engineering students in underrepresented groups have participated. As scholars in this program, these students have:

- Developed relationships within their mentor/mentee team

- Attended seminars that advise them of engineering career options

- Became familiar with various learning centers and counseling services

- Participated in workshops that prepared them to apply and interview for jobs, and

- Received financial aid 
The faculty advisors of GUIDE plan to continue the program in the future with funding provided by the National Science Foundation. 


\section{Acknowledgements}

The authors would like to gratefully acknowledge the National Science Foundation (grant number DUE-0220500) and MTU, College of Engineering for their support of this work. We also thank the engineering faculty and professionals and the Harold Meese Center for their seminars and workshops.

\section{References}

[1] James, William, http://www.brainyquotes.com/quotes/authors/w/williamjam132339.html

[2] Tinto, V., 1993, "Leaving College: Rethinking the Causes and Cures of Student Attrition", Second Edition, University of Chicago Press, Chicago, Illinois.

[3] Monte, A.E., Hein, G.L., 2004, “An Innovative Program to Support Undergraduate Engineering Students from Underrepresented Groups".

[4] Touton, S. H., GUIDE Survey, December 2003.

[5] Monte, A.E., GUIDE Scholar End of Semester Interviews, December 2003.

[6] Hein, G.L., Monte, A.E., "A Student Mentoring and Development Program for Underrepresented Groups in Engineering", $34^{\text {th }}$ ASEE/IEEE Frontiers in Education Conference, October 2004, In Press.

\section{Biographies}

SAYWARD H. TOUTON - Sayward Touton is a Civil Engineering graduate student in the Peace Corps Master's International program at Michigan Technological University. She received her BS in Civil Engineering at Tennessee Technological University. Currently she is conducting research for the Michigan Tech Transportation Institute investigating the long term effects of deicers on pavement and structural concrete.

CORY P. MCDONALD - Cory McDonald is an Environmental Engineering graduate student in the Peace Corps Master's International program at Michigan Technological University. He received his BS in Civil Engineering at Michigan State University.

AMY E. MONTE - Amy Monte is a lecturer in the Department of Engineering Fundamentals at Michigan Technological University. She received her BS and MS in Environmental Engineering a Michigan Technological University. Amy teaches Foundations of Engineering I and II and Engineering and Science Applications in PreCalculus. Amy is also an academic advisor of students in Engineering Undecided and Biomedical Engineering.

GRETCHEN L. HEIN - Gretchen Hein is a lecturer in the Department of Engineering Fundamentals at Michigan Technological University. She received her BSME a Kettering University in Flint, MI and her MSE at Purdue University in West Lafayette, IN. Prior to pursuing her master's degree she worked as a mechanical engineer a General Motors Corporation. She received her PhD from Michigan Technological University. Gretchen teaches Foundations of Engineering I and II, and Engineering and Science Applications in Pre-Calculus. 
Appendix A - GUIDE Student Survey, December 2003

1.) List all the activities that your team did together this semester. Make two lists, one indicating which activities were for fun and which were academically (if any) related.

2.) List the benefits (besides the scholarship) you believe you are getting out of mentoring/getting mentored. Answers should vary depending on the role you had in the group.

Grad student:

$2^{\text {nd }}$ year student:

Freshman:

3.) Grad student: Did you understand the purpose and objectives of this program, especially your role as a mentor? Please explain.

4.) $2^{\text {nd }}$ year student: How is your role this year different than last year? Has being mentored made your semester any easier?

5.) Freshmen: Compared to your friends who are not in the program, do you think that your first semester at Tech was made an easier through being mentored? And, do you share things that you have learned from the seminars with your friends? Give some examples. 